\title{
A novel feeding behavior by an ambush predator on toxic prey
}

Received: 30 August 2008/ Accepted: 25 September 2008/Published online: 16 October 2008

(C) Springer-Verlag 2008

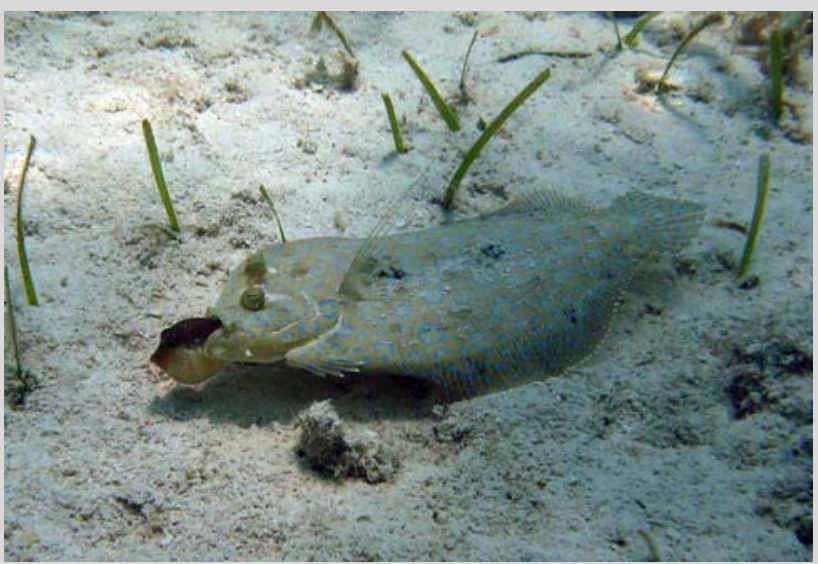

Fig. 1 Canthigaster rostrata inflated after partial ingestion by Bothus lunatus
Piscivory among reef fishes is rarely observed by divers, particularly during daylight hours. Here we describe predation by the peacock flounder, Bothus lunatus (Linnaeus 1758), on the Caribbean sharpnose puffer, Canthigaster rostrata (Bloch 1786), on a reef in the Exuma Cays, Bahamas. Sharpnose puffers are in the Family Tetraodontidae, and contain the potent neurotoxin tetrodotoxin in their mucus, skin, and tissues (Nuñez-Vázquez et al. 2000). Thus, while fishes of this genus tend to be abundant in coral reef communities and their diminutive size would suggest them to be susceptible to piscivory, predation pressure on these species is generally presumed to be low (Allen and Randall 1977). To date, the only published reports of $C$. rostrata in gut contents are on a barracuda (Randall 1967) and seabirds (Hensley and Hensley 1995).

We observed an adult peacock flounder detect a hovering pufferfish, lunge, and strike. The pufferfish immediately inflated such that most of its body was not ingested (Fig. 1), and the flounder proceeded to rap the pufferfish against the substrate several times in an apparent effort to daze or deflate its prey. After several attempts, the pufferfish remained inflated, but the flounder was finally able to ingest its prey. We watched for several minutes post-ingestion, but the pufferfish was not regurgitated, and the flounder demonstrated no apparent adverse neurological responses. This observation suggests that predation pressure on sharpnose puffers may be greater than previously suspected, particularly by fishes able to withstand a dose of toxin. $B$. lunatus appears to have developed a unique feeding behavior to effectively stun its prey.

\section{References}

Allen GR, Randall JE (1977) Review of the sharpnose pufferfishes (subfamily Canthigasterinae) of the Indo-Pacific. Rec Aust Mus 30:475-517

Hensley VI, Hensley DA (1995) Fishes eaten by sooty terns and brown noddies in the Dry Tortugas, Florida. Bull Mar Sci 56:813-821

Nuñez-Vázquez EJ, Yotsu-Yamashita M, Sierra-Beltrán AP, Yasumoto T, Ochoa JL (2000) Toxicities and distribution of tetrodotoxin in the tissues of puffer fish found in the east coast of the Baja California Peninsula, Mexico. Toxicon 38:729-734

Randall JE (1967) Food habits of reef fishes of the West Indies. Stud Trop Oceanogr 5:665-847

D. J. Gochfeld $(\bowtie)$

National Center for Natural Products Research, University of Mississippi, P.O. Box 1848, University, MS 38677, USA

e-mail: gochfeld@olemiss.edu

\section{J. B. Olson}

Department of Biological Sciences, University of Alabama, Campus Box 870344, Tuscaloosa, AL 35487, USA

e-mail: jolson@bama.ua.edu

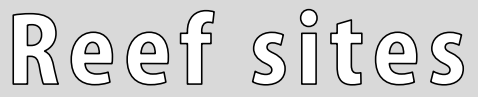

Coral Reefs (2009) 28:155

DOI $10.1007 / \mathrm{s} 00338-008-0436-x$ 